\title{
Nitrogen mineralization, nitrification and denitrification in upland and wetland ecosystems
}

\author{
Donald R. Zak ${ }^{1,2, *}$ and David F. Grigal ${ }^{2}$ \\ Departments of ${ }^{1}$ Soil Science, and of ${ }^{2}$ Ecology, Evolution, and Behavior, University of Minnesota, St. Paul, MN 55108, USA
}

Received November 6, 1990 / Accepted in revised form June 18, 1991

Summary. Nitrogen mineralization, nitrification, denitrification, and microbial biomass were evaluated in four representative ecosystems in east-central Minnesota. The study ecosystems included: old field, swamp forest, savanna, and upland pin oak forest. Due to a high regional water table and permeable soils, the upland and wetland ecosystems were separated by relatively short distances ( 2 to $5 \mathrm{~m}$ ). Two randomly selected sites within each ecosystem were sampled for an entire growing season. Soil samples were collected at 5 -week intervals to determine rates of $\mathrm{N}$ cycling processes and changes in microbial biomass. Mean daily $\mathrm{N}$ mineralization rates during five-week in situ soil incubations were significantly different among sampling dates and ecosystems. The highest annual rates were measured in the upland pin oak ecosystem $\left(8.6 \mathrm{~g} \mathrm{~N} \mathrm{~m}^{-2} \mathrm{yr}^{-1}\right)$, and the lowest rates in the swamp forest (1.5 $\left.\mathrm{g} \mathrm{N} \mathrm{m}^{-2} \mathrm{yr}^{-1}\right)$; nitrification followed an identical pattern. Denitrification was relatively high in the swamp forest during early spring $(8040 \mu \mathrm{g}$ $\left.\mathrm{N}_{2} \mathrm{O}-\mathrm{N} \mathrm{m}^{-2} \mathrm{~d}^{-1}\right)$ and late autumn $\left(2525 \mu \mathrm{g} \mathrm{N}_{2} \mathrm{O}-\mathrm{N}\right.$ $\mathrm{m}^{-2} \mathrm{~d}^{-1}$ ); nitrification occurred at rates sufficient to sustain these losses. In the well-drained uplands, rates of denitrification were generally lower and equivalent to rates of atmospheric $\mathrm{N}$ inputs. Microbial $\mathrm{C}$ and $\mathrm{N}$ were consistently higher in the swamp forest than in the other ecosystems; both were positively correlated with average daily rates of $\mathrm{N}$ mineralization. In the subtle landscape of east-central Minnesota, rates of $\mathrm{N}$ cycling can differ by an order of magnitude across relatively short distances.

Key words: $\mathrm{N}$ mineralization - Nitrification - Microbial biomass - Denitrification - Spatial variability

Landscapes consist of numerous ecosystems differing in plant species composition and in the fundamental processes that regulate nitrogen $(\mathrm{N})$ availability and loss

\footnotetext{
* Present address and address for offprint requests: School of Natural Resources, University of Michigan, Ann Arbor, MI 48109-1115, USA
}

(Vitousek et al. 1982; Nadelhoffer et al. 1983; Pastor et al. 1984; Schimel et al. 1985; Davidson and Swank 1987). While differing in many respects, some terrestrial ecosystems are linked to one another through the transfer of energy and nutrients. For example, ecosystems in upslope positions typically contribute water, nutrients, and organic matter to those downslope. Determining the origin of this material in lower slope positions is often difficult because both carbon (C) and $\mathrm{N}$ can be either fixed in situ or transported from upslope positions (Schimel et al. 1985). Differences in $\mathrm{N}$ cycling along topographic gradients can also arise through the influence of temperature, moisture, and substrate availability on microbial activity (Schimel et al. 1985; Davidson and Swank 1987; Burke 1989; Groffman and Tiedje 1989).

Swamp and riparian forests occur in topographic positions where material can enter through both horizontal (down-slope transport) and vertical (atmospheric) vectors. Most early and mid-successional wetland forests are thought to function as nutrient sinks within the landscape (Engler and Patrick 1974; Kitchens et al. 1975; Verry and Timmons 1982; Lowrance et al. 1984a; 1984b). In some watersheds, uplands under agricultural management can yield relatively large quantities of $\mathrm{NO}_{3}^{-}$ that eventually enter riparian forests through subsurface flow (Jackson et al. 1973; Lowrance et al. 1984a; Peterjohn and Correll 1984). Because plant uptake and denitrification are important processes within these ecosystems, subsequent losses of $\mathrm{NO}_{3}^{-}$to streamflow are often small (Lowrance 1984a). In the Lake States region, forests on poorly-drained soils exhibit relatively high rates of denitrification compared to those on welldrained upslope sites (Groffman and Tiedje 1989).

In the subtle topography of east-central Minnesota (USA), the regional water table lies at a shallow depth below the soil surface and provides a physical link between upland and wetland ecosystems. Relatively small differences in elevation, and hence in depth to the water table, give rise to marked changes in plant species composition and edaphic conditions; these changes often occur across distances of only a few meters. The spatial 
arrangement and physical connection between uplands and wetlands allows for a linkage of $\mathrm{N}$ cycling processes. Although nitrification can occur within upland ecosystems (Zak et al. 1990a, 1990b) and $\mathrm{NO}_{3}^{-}$is highly mobile within the soil, leaching and transport to wetlands seems unlikely. Plant productivity in east-central Minnesota is largely limited by $\mathrm{N}$ availability (Tilman 1986, 1987), and a high demand by actively growing plants should lead to net retention by rather than a net export of $\mathrm{N}$ from ecosystems. If denitrification is an important process within wetlands, then the amount of $\mathrm{N}$ loss should be highly dependent on in situ rates of $\mathrm{NO}_{3}^{-}$production.

While a great deal is known regarding the factors influencing $\mathrm{N}$ availability and denitrification, relatively few studies have attempted to link spatial and temporal patterns of these processes (Robertson 1986; Matson and Vitousek 1987; Davidson and Swank 1987; Groffman and Tiedje 1989). Davidson and Swank (1987) concluded that denitrification was likely to be an important process in poorly drained surface soils of forests with high nitrification rates. Identifying these kinds of sites could aid in understanding relatively large-scale patterns of $\mathrm{N}$ availability and loss. Our objectives were to: (i) link spatial and temporal patterns of $\mathrm{N}$-cycling processes at a landscape scale, and (ii) determine if denitrification represented an important $\mathrm{N}$ loss from upland and wetland ecosystems in east-central Minnesota. Our approach was to study the dynamics of $\mathrm{N}$ mineralization, nitrification, denitrification, and microbial biomass within several ecosystems that commonly occur throughout this region.

\section{Methods}

\section{Study site}

The Cedar Creek Natural History Area (CCNHA) is located approximately $50 \mathrm{~km}$ north of Minneapolis, Minnesota USA. It has a continental climate and receives $660 \mathrm{~mm}$ of annual precipitation; mean annual temperature is $6^{\circ} \mathrm{C}$ (Grigal et al. 1974). The CCNHA lies within the Anoka Sand Plain which is composed of deep $(20 \mathrm{~m})$ well sorted outwash sands. The regional water table is at or near the soil surface in low-lying areas and is only several meters below the surface in the highest elevations. Due to subtle topography, regional hydrology, and permeable soil materials, the study area is composed of numerous wetland and upland ecosystems. These ecosystems often lie in close proximity to one another, with only a few meters of horizontal distance separating upland oak forest or old field from adjacent wetlands. Prior to European settlement, a large proportion of the study area was prairie, and many of the present ecosystems have developed following agricultural abandonment. We studied rates of $\mathrm{N}$ cycling and loss in four ecosystems that encompassed large land areas and were representative of the study area. These ecosystems included: old field, swamp forest, savanna, and upland pin oak (Quercus ellipsoidalis E.J. Hill) forest.

Old fields and savanna dominate landscape positions where fires were once frequent. The old field ecosystems vary in age from 1 to 60 years following abandonment; we selected sites that had been abandoned for at least 50 years. Dominant species in the old fields include: Schizachyrium scoparium Michx., Andropogon gerardii Vitman, Artemisia ludoviciana Nutt., and Poa pratensis L. Scattered individuals of Quercus macrocarpa Michauex form a sparse overstory within the savannas; prairie grasses, sedges, and forbs are common in this ecosystem. Dominant non-woody species include: Sorghastum nutans (L.), Poa pratensis L., Carex muhlenbergii Schkuhr, and Artemisia ludoviciana Nutt. Soils of the savanna and old fields are classified as Alfic and Typic Udipsamments, respectively (Table 1; Grigal et al. 1974).

We studied $\mathrm{N}$ dynamics within a swamp forest dominated by Fraximus nigra Marshall and Acer rubrum L. for several reasons. It is a common wetland ecosystem in the CCNHA, and it often lies downslope from the upland forests, savanna, and old fields. Because the water table is at or neat the soil surface for most of the year, rooting is shallow and windthrow is common. As a consequence, the overstory trees form a somewhat open canopy allowing ample light to reach a well-developed groundflora layer. The poorlydrained soils in this landscape position are organic and classified as Typic Borosaprists (Table 1; Grigal et al. 1974).

Upland pin oak forest occurs in the well-drained uplands of the CCNHA. It is characterized by an even-aged overstory of Quercus ellipsoidalis with a dense tall-shrub layer dominated by Corylus americana Walter and C. cormuta Marshall. The sparse groundflora layer is composed of Carex sp., Gaultheria procumbens L., and several species of moss. The soils beneath this forest are classified as Alfic Udipsamments (Table 1; Grigal et al. 1974).

From field observations, we initially located four possible study sites within each ecosystem type. Sites were identified by similarities in plant species composition, soil development and topographic position. We randomly selected two sites within each ecosystem for the present study. The old field, savanna, and upland pin oak forest sites covered at least 1 ha with no evidence of recent disturbance. Swamp forests often extend as narrow bands between upland and aquatic ecosystems. As a consequence, these sites were smaller in size compared to the upland sites, but our sampling points were entirely within their boundaries. Within each site, a $20-\mathrm{m}$ transect was randomly established for soil sampling. Each transect was oriented in a north-south direction and soil samples were collected at 5-m intervals for $\mathrm{N}$ mineralization, nitrification, microbial biomass, and denitrification. In each ecosystem $(n=4)$, we collected 5 soil samples per site $(n=2)$ on each sampling date $(n=6)$; sampling was carried out from 12 May to 11 November 1987. At the termination of the study, an additional set of soil samples was collected to determine soil bulk density.

\section{Net $N$ mineralization and nitrification}

We used an in situ soil incubation procedure to determine $\mathrm{N}$ mineralization and nitrification (sensu Rapp et al. 1979). Soil cores,
Table 1. Surface soil $(0$ to $10 \mathrm{~cm})$ properties of upland and wetland ecosystems in east-central Minnesota

\begin{tabular}{|c|c|c|c|c|c|c|}
\hline & \multirow[t]{2}{*}{ Texture } & \multirow[t]{2}{*}{ Drainage } & \multirow{2}{*}{$\begin{array}{l}\mathrm{D}_{\mathrm{b}} \\
\mathrm{Mg} \mathrm{m}\end{array}$} & \multirow[t]{2}{*}{$\mathrm{pH}$} & Organic $\mathrm{C}$ & Total N \\
\hline & & & & & \multicolumn{2}{|l|}{$\mathrm{g} \mathrm{m^{-2 }}$} \\
\hline Old Field & sand & excessively & 1.4 & 4.6 & 2083 & 106 \\
\hline Swamp & - & very poorly & 0.2 & 5.6 & 4960 & 344 \\
\hline Savanna & fine sand & excessively & 1.3 & 5.8 & 2730 & 125 \\
\hline Upland Pin Oak & fine sand & excessively & 1.3 & 5.8 & 3228 & 146 \\
\hline
\end{tabular}

Note: Soil texture, drainage, and $\mathrm{pH}$ have been summarized from Grigal et al. 1974. Organic-C was determined with a Leco $\mathrm{C}$ analyzer, and total $\mathrm{N}$ was measured colorimetrically following $\mathrm{H}_{2} \mathrm{SO}_{4}$ digestion 
$3.8 \mathrm{~cm}$ in diameter and $10 \mathrm{~cm}$ in depth, were collected at each sampling point and date. Cores were collected within a $15-\mathrm{cm}$ length of PVC tubing, placed in polyethylene bags, and returned to the laboratory for analysis. A second PVC tube was driven into the soil at the same time, but was not removed from the soil profile. A Styrofoam cup was anchored to the top of the open tube to prevent $\mathrm{N}$ leaching from rain and throughfall. In the swamp forest, we placed a small polyethylene bag over the bottom of each tube to prevent leaching losses from the rising and falling watertable. Samples ( 5 per site) were incubated in situ for five 5 -week periods from 12 May to 11 November 1987. Samples were not incubated from mid-November to April because less than $1 \%$ of annual $\mathrm{N}$ mineralization and nitrification occurs during this period (Zak et al. 1990b).

In the laboratory, $10 \mathrm{-g}$ field-moist samples of both initial and field incubated soil were extracted with $20 \mathrm{ml}$ of $2 \mathrm{M} \mathrm{KCl}$, and the filtrates were analyzed for $\mathrm{NH}_{4}^{+}-\mathrm{N}$ and $\mathrm{NO}_{3}^{-}-\mathrm{N}$ using a Technicon Autoanalyzer II (Technicon 1977; 1978). Additional 10-g soil samples were dried at $105^{\circ} \mathrm{C}$ to determine field moisture content. Data were adjusted to an oven-dry basis. $N$ et $\mathrm{N}$ mineralization was considered to be the increase in $\mathrm{NH}_{4}^{+}-\mathrm{N}+\mathrm{NO}_{3}^{-}-\mathrm{N}$ between incubated and initial soil samples, and net nitrification was considered to be the difference in $\mathrm{NO}_{3}^{-}-\mathrm{N}$ concentrations. Annual mineralization rates $\left(\mathrm{g} \mathrm{N} \mathrm{m}^{-2} \mathrm{yr}^{-1}\right)$ were calculated by summing inorganic $\mathrm{N}$ production over the five incubation periods; annual rates of nitrification were calculated analogously. Mineralization and nitrification were expressed as mean daily rates $\left(\mathrm{mg} \mathrm{N} \mathrm{m}^{-2} \mathrm{~d}^{-1}\right)$ during the 5-week incubation and as mean annual totals.

\section{Microbial biomass $C$ and $N$}

Initial soil cores were analyzed for microbial $\mathrm{C}$ and $\mathrm{N}$ using the $\mathrm{CHCl}_{3}$ fumigation-incubation procedure (Jenkinson and Powlson 1976; Voroney and Paul 1984). A 20-g subsample of field-moist soil was fumigated with $\mathrm{C}_{2} \mathrm{H}_{5} \mathrm{OH}$-free $\mathrm{CHCl}_{3}$ for $18 \mathrm{~h}$ in a moist vacuum desiccator. A second 20 -g subsample, a control, was maintained at room temperature in a moist desiccator during the $18 \mathrm{~h}$ fumigation. Each fumigated sample was inoculated with $0.5 \mathrm{~g}$ of fresh soil, and both control and fumigated samples were incubated $\left(22^{\circ} \mathrm{C}\right)$ in sealed glass jars for $10 \mathrm{~d}$. Following incubation, a sample of air-space gas was removed and its $\mathrm{CO}_{2}$ concentration was determined using a Varian 3700 gas chromatograph equipped with a thermal conductivity detector. Carbon dioxide was separated from other atmospheric constituents on a Porapak Q column maintained at $55^{\circ} \mathrm{C}$ with $\mathrm{He}\left(35 \mathrm{ml} \mathrm{min}^{-1}\right)$ as a carrier gas. Both control and fumigated samples were extracted with $1 \mathrm{M} \mathrm{KCl}$ and analyzed for $\mathrm{NH}_{4}^{+}$and $\mathrm{NO}_{3}^{-}$as described above. Microbial biomass $\mathrm{C}$ and $\mathrm{N}$ were calculated using the equations of Voroney and Paul (1984).

\section{Denitrification}

At each sampling point and date, one soil core was collected to determine denitrification using the $\mathrm{C}_{2} \mathrm{H}_{2}$-inhibition procedure (Tiedje 1982; Tiedje et al. 1989). Samples for denitrification were nearly identical to those collected for $\mathrm{N}$ mineralization; an intact soil core was extracted from the soil surface $(0$ to $10 \mathrm{~cm})$ within a PVC tube. However, the bottom of each tube was immediately sealed with a rubber stopper, and the cores were returned to the laboratory; all samples were assayed within $4 \mathrm{~h}$ of field collection. In the laboratory, the top of each core was sealed with a rubber stopper that contained a septa for gas sampling. Acetylene, generated from $\mathrm{CaC}_{2}$ and $\mathrm{H}_{2} \mathrm{O}$, was added through the septa to produce a concentration of $10 \mathrm{kPa}$; it was thoroughly mixed with head-space gases by repeated pumping with a $20 \mathrm{ml}$ syringe. Cores were incubated for $6 \mathrm{~h}$ at $22^{\circ} \mathrm{C}$, and samples for $\mathrm{N}_{2} \mathrm{O}$ analysis were withdrawn at 2 and $6 \mathrm{~h}$. Prior to each sampling, the head-space contents were thoroughly mixed by the procedure described above. Individual gas samples were stored in $3 \mathrm{ml}$ evacuated glass vials (Venoject ${ }^{\text {tm }}$, Terumo Scientific, N.J.) until they could be analyzed, usually within 1 week. Nitrous oxide concentrations were determined using a Varian 3700 gas chromatograph with a hot $\left(350^{\circ} \mathrm{C}\right)$ electron capture detector. Samples were chromatographed on a Porapak Q column $\left(55^{\circ} \mathrm{C}\right)$ using $5 \% \mathrm{CH}_{4}: 95 \% \mathrm{Ar}$ as a carrier gas (35 $\mathrm{ml} \mathrm{min}^{-1}$ ). The air-space volume of each core was determined with a pressure transducer (Parkin et al. 1984), and total $\mathrm{N}_{2} \mathrm{O}$ production was corrected for the amount of $\mathrm{N}_{2} \mathrm{O}$ dissolved in soil $\mathrm{H}_{2} \mathrm{O}$ (Tiedje 1982). Denitrification was calculated as the rate of $\mathrm{N}_{2} \mathrm{O}$ production during 2 and $6 \mathrm{~h}$. Preliminary time-course studies indicated that rates were linear during this time period. Denitrification in the four ecosystems is presented as the mean daily rate ( $\mu \mathrm{g} \mathrm{N}_{2} \mathrm{O}-\mathrm{N} \mathrm{m}^{-2} \mathrm{~d}^{-1}$ ) on each sampling date.

\section{Statistical analysis}

An analysis of variance for a nested design (i.e., sites nested within ecosystems) was used to test for significant differences in extractable $\mathrm{N}$, rates of mineralization and nitrification, and microbial biomass among the sampling dates, ecosystems, and sites (SAS 1987). Date and ecosystem were considered fixed variables and sites were random. Treatment means were compared using a protected Fisher's LSD procedure with significance accepted at alpha $=0.05$. Due to a skewed distribution, we did not statistically analyze the denitrification data. We have, therefore, only presented mean daily rates and their standard errors. Linear regression analysis was used to explore the relationship between microbial biomass pools and rates of $\mathrm{N}$ mineralization in the four ecosystem types. Regression analyses were also used to relate denitrification rates to nitrification rates and extractable- $\mathrm{NO}_{3}^{-}$pools.

\section{Results}

Extractable $\mathrm{NH}_{4}^{+}$and $\mathrm{NO}_{3}^{-}$pools were significantly different among the sampling dates and ecosystems (Fig. 1A and $\mathrm{B}$ ). In general, extractable $\mathrm{NH}_{4}^{+}$(averaged over sampling dates) was greatest in the upland pin oak forest and least in the old field ecosystem. Extractable $\mathrm{NH}_{4}^{+}$was relatively constant in the old field ecosystem in relation to the other ecosystem types. Pools in the savanna and upland pin oak forest were significantly greater in early spring compared to the remaining sampling dates (Fig. 1A). Extractable $\mathrm{NO}_{3}^{-}$displayed a similar temporal pattern (Fig. 1B). The greatest quantities of $\mathrm{NO}_{3}^{-}$were measured in the upland pin oak ecosystem $(2470 \mathrm{mg}$ $\mathrm{N} \mathrm{m}^{-2}$ ) on the 12 May sampling date (Fig. 1B). Nitrate pools ranged between 70 and $570 \mathrm{mg} \mathrm{N} \mathrm{m}^{-2}$ in the swamp ecosystem (Figure 1B), while the temporal variation within the savanna and old field ecosystems was much less. Both extractable $\mathrm{NH}_{4}^{+}$and $\mathrm{NO}_{3}^{-}$concentrations were not significantly different between sites within any ecosystem type.

Net $\mathrm{N}$ mineralization, as measured by the in situ incubation procedure, also displayed a significant temporal pattern (Fig. 2A). With the exception of the two autumn sampling dates, mean daily mineralization rates were greater in the upland pin oak forest than in the other ecosystem types (Fig. 2A). Rates in this ecosystem were high in early spring and then steadily declined during mid-summer through the onset of winter (Fig. 2A). Mean daily mineralization rates were never significantly different between the old field and savanna, and ranged from 5 to $32 \mathrm{mg} \mathrm{N} \mathrm{m}^{-2} \mathrm{~d}^{-1}$. Negative daily rates of net $\mathrm{N}$ mineralization (i.e., net immobilization or deni- 

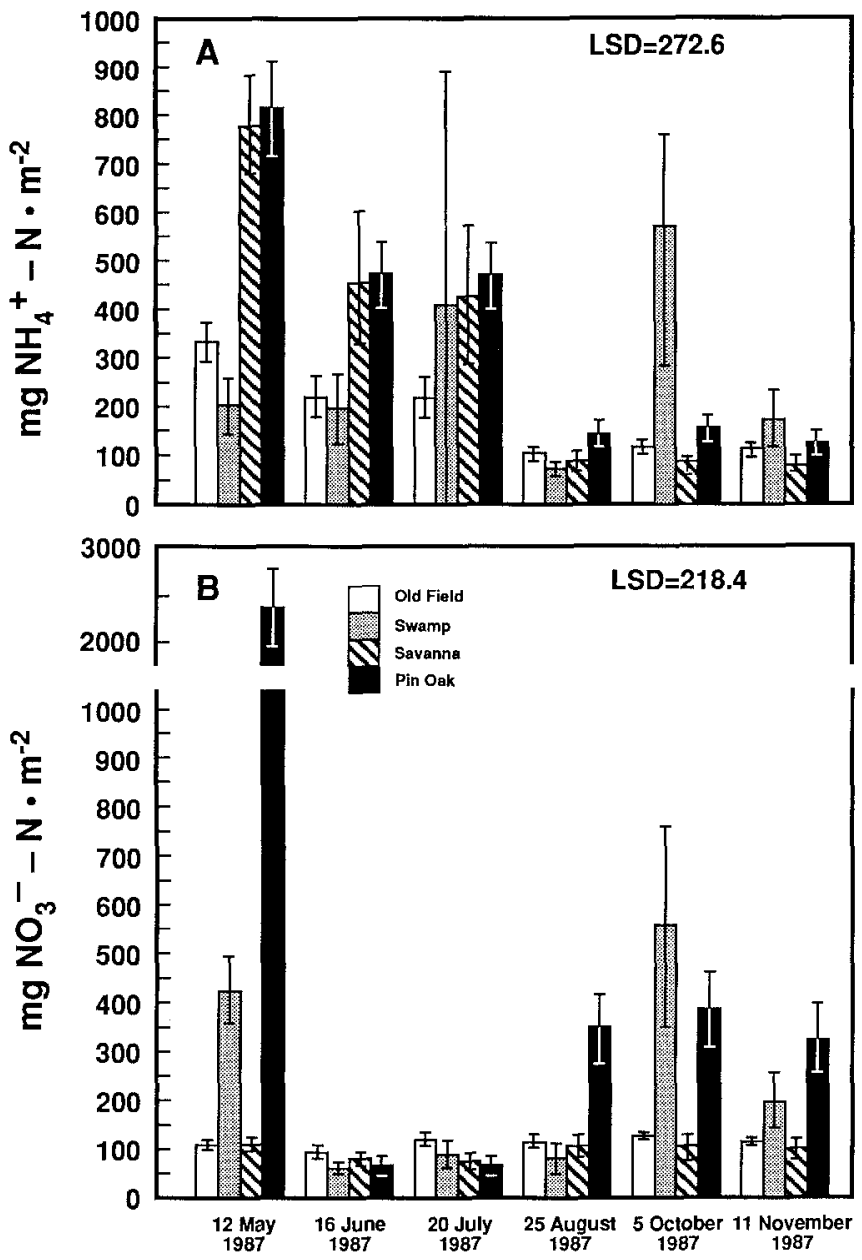

Fig. 1. Extractable $\mathrm{NH}_{4}^{+}$(A) and $\mathrm{NO}_{3}^{-}$(B) in the surface soil of upland and wetland ecosystems in east-central Minnesota. Values are ecosystem means $(n=10)$ measured at five-week intervals during the 1987 growing season. The bars within the figure represent the standard error for each mean

trification) occurred during late fall in the upland pin oak ecosystem (Fig. 2A). Sites within an ecosystem type were not significantly different during any of the sampling periods.

Mean daily rates of nitrification were highly variable among sampling dates and ecosystems (Fig. 2B). The highest rates were measured in the upland pin oak ecosystem during May 1987 (80 $\left.\mathrm{mg} \mathrm{N} \mathrm{m}^{-2} \mathrm{~d}^{-1}\right)$. Rates were also high in the swamp ecosystem during late summer (36 $\mathrm{mg} \mathrm{N} \mathrm{m}^{-2} \mathrm{~d}^{-1}$; Fig. 2B). These two rates were significantly greater than all others. Nitrification rates in the old field and savanna did not differ significantly on any sampling date, nor did they differ from rates in the upland pin oak ecosystem except during the first sampling period. Daily rates were not significantly different among sites within an ecosystem type for any of the sampling periods.

Annual $\mathrm{N}$ mineralization in the upland pin oak ecosystem $\left(8.6 \mathrm{~g} \mathrm{~N} \mathrm{~m}^{-2} \mathrm{yr}^{-1}\right)$ was significantly greater than rates in the other ecosystem types. Approximately $50 \%$ of this annual production occurred during 12 May to 16 June. Annual rates were not significantly different in the
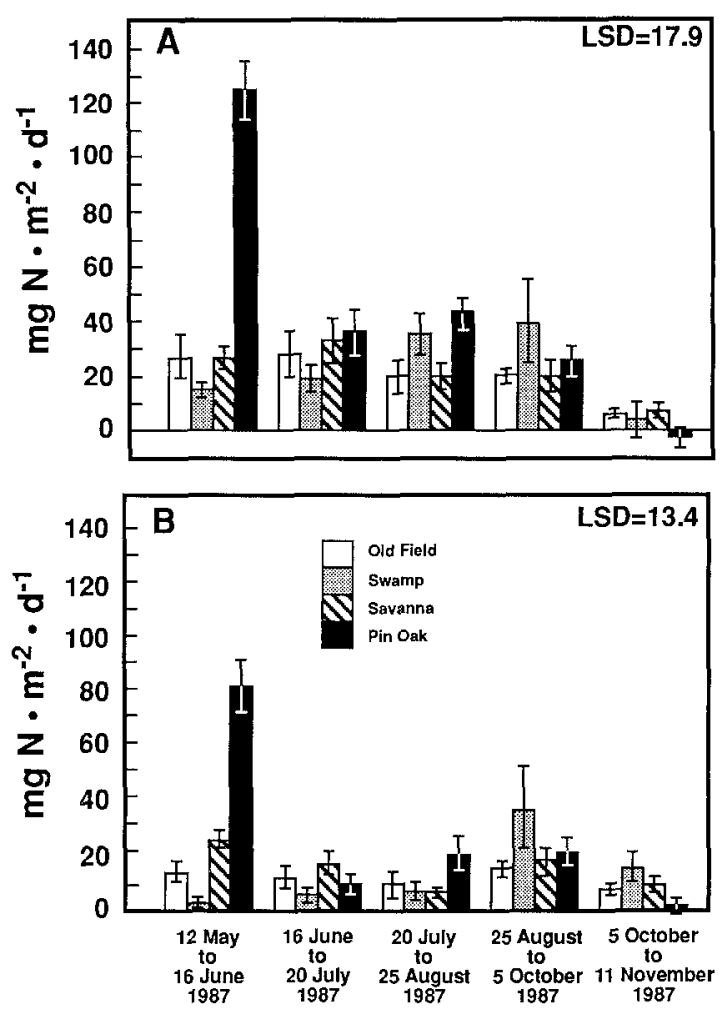

Fig. 2. Mean daily rates of net $\mathrm{N}$ mineralization (A) and net nitrification (B) during five-week in situ soil incubations. Soils were incubated during the 1987 growing season, and ecosystem means are presented along with their standard error

old field and savanna (ca. $3.8 \mathrm{~g} \mathrm{~N} \mathrm{~m}^{-2} \mathrm{yr}^{-1}$ ), but these rates were significantly greater than rates measured in the swamp forest $\left(1.5 \mathrm{~g} \mathrm{~N} \mathrm{~m}^{-2} \mathrm{yr}^{-1}\right)$. There were significant differences in annual $\mathrm{N}$ mineralization among sites within an ecosystem type. For example, there was a two-fold difference in rates between the two old field sites. Differences among the upland pin oak stands were less pronounced, but still significant (Table 2). Annual rates of nitrification were significantly different among all the ecosystem types (Table 2). Rates were lowest in the swamp forest, greater in the old field and savanna, and were highest in the upland pin oak forest. There was a significant two-fold difference in annual nitrification between the upland pin oak sites; rates did not differ significantly between other sites within an ecosystem type (Table 2).

Microbial biomass $\mathrm{C}$ and $\mathrm{N}$ were significantly different among the sampling dates and ecosystems (Figs. $3 \mathrm{~A}$ and $\mathrm{B}$ ). For the August through November sampling dates, microbial $C$ was significantly greater in the swamp ecosystem than in the other ecosystem types. Microbial $\mathrm{C}$ and $\mathrm{N}$ did not differ significantly among the old field, savanna, and upland pin oak ecosystems on any sampling date. Mean microbial biomass $\mathrm{C}$ and $\mathrm{N}$ (averaged over sampling dates) were significantly different among sites within an ecosystem type. Average microbial $\mathrm{C}$ in the swamp ecosystem was $80 \mathrm{~g} \mathrm{C} \mathrm{m}^{-2}$ and $165 \mathrm{~g} \mathrm{C} \mathrm{m}^{-2}$ $(\mathrm{LSD}=52)$ in sites 1 and 2, respectively. Significant differences in microbial $\mathrm{N}$ were present between sites in 
Table 2. Annual rates of net $\mathrm{N}$ mineralization and nitrification in upland and wetland ecosystems. Values are means with standard error in parentheses for each ecosystem type and for the two sites nested within them. Means in a column that have the same letter are not significantly different at alpha $=0.05$

\begin{tabular}{|c|c|c|c|c|}
\hline & \multicolumn{2}{|c|}{ Mineralization } & \multicolumn{2}{|c|}{ Nitrification } \\
\hline & Ecosystem & Site & Ecosystem & Site \\
\hline & $\overline{\mathrm{g} \mathrm{N} \mathrm{m}^{-2} \mathrm{y}}$ & & & \\
\hline \multirow[t]{2}{*}{ Old Field } & $\begin{array}{c}3.5^{\mathrm{b}} \\
(0.69)\end{array}$ & & $\begin{array}{c}2.0^{\mathrm{b}} \\
(0.43)\end{array}$ & \\
\hline & & $\begin{array}{c}2.3^{\mathrm{a}} \\
(1.03) \\
4.8^{\mathrm{b}} \\
(2.50)\end{array}$ & & $\begin{array}{c}1.7^{\mathrm{a}} \\
(0.89) \\
2.4^{\mathrm{a}} \\
(1.81)\end{array}$ \\
\hline \multirow[t]{2}{*}{ Swamp } & $\begin{array}{c}1.5^{\mathrm{a}} \\
(0.16)\end{array}$ & & $\begin{array}{c}0.7^{\mathrm{a}} \\
(0.09)\end{array}$ & \\
\hline & & $\begin{array}{c}1.2^{\mathrm{a}} \\
(0.49) \\
1.8^{\mathrm{a}} \\
(0.44)\end{array}$ & & $\begin{array}{c}0.6^{\mathrm{a}} \\
(0.41) \\
0.8^{\mathrm{a}} \\
(0.15)\end{array}$ \\
\hline \multirow[t]{2}{*}{ Savanna } & $\begin{array}{c}4.2^{\mathrm{b}} \\
(0.47)\end{array}$ & & $\begin{array}{c}3.0^{\mathrm{c}} \\
(0.40)\end{array}$ & \\
\hline & & $\begin{array}{c}3.4^{\mathrm{a}} \\
(1.39) \\
5.0^{\mathrm{a}} \\
(1.27)\end{array}$ & & $\begin{array}{c}2.3^{\mathrm{a}} \\
(1.17) \\
3.8^{\mathrm{a}} \\
(0.94)\end{array}$ \\
\hline \multirow[t]{2}{*}{ Upland Pin Oak } & $\begin{array}{c}8.6^{c} \\
(0.92)\end{array}$ & & $\begin{array}{c}5.0^{\mathrm{d}} \\
(0.70)\end{array}$ & \\
\hline & & $\begin{array}{c}7.2^{\mathrm{a}} \\
(2.99) \\
10.0^{\mathrm{b}} \\
(2.37)\end{array}$ & & $\begin{array}{c}3.4^{\mathrm{a}} \\
(1.43) \\
6.7^{\mathrm{b}} \\
(1.39)\end{array}$ \\
\hline LSD* & 1.60 & 2.22 & 1.00 & 1.51 \\
\hline
\end{tabular}

* Note: The LSD for sites is used to compare means within an ecosystem type

both swamp (site $1=3.4 \mathrm{~g} \mathrm{~N} \mathrm{~m}^{-2}$; site $2=9.5 \mathrm{~g} \mathrm{~N} \mathrm{~m}^{-2}$; $\mathrm{LSD}=2.46$ ) and upland pin oak ecosystems (site $1=$ $3.4 \mathrm{~g} \mathrm{~N} \mathrm{~m}^{-2}$; site $2=5.8 \mathrm{~g} \mathrm{~N} \mathrm{~m}^{-2}$ ). At both the ecosystem and individual site level, we found no relationship between average daily rates of $\mathrm{N}$ mineralization and microbial biomass (e.g., mineralization rates from 12 May to 16 June and microbial $\mathrm{C}$ or $\mathrm{N}$ on 16 June). However, annual means of daily $\mathrm{N}$ mineralization and microbial $\mathrm{N}$ displayed a weak positive correlation among individual sites $(0.55+5.24($ microbial $\mathrm{N})=$ mineralization; $\mathrm{r}^{2}=0.40, p<0.001, n=8$ : where microbial $\mathrm{N}=\mathrm{mg} \cdot \mathrm{N}$ $\mathrm{m}^{-2}$ and mineralization $=\mathrm{mg} \mathrm{N} \mathrm{m} \mathrm{N}^{-2} \mathrm{~d}^{-1}$ ).

Denitrification rates were relatively high in the swamp ecosystem, and fluxes ranged from 75 to $8040 \mu \mathrm{g} \mathrm{N}{ }_{2} \mathrm{O}-\mathrm{N}$ $\mathrm{m}^{-2} \mathrm{~d}^{-1}$ during the six months of sampling. Denitrification in the sandy well-drained upland ecosystems was minimal during the growing season with the highest rate measured in the savanna on 16 June $\left(2700 \mu \mathrm{g} \mathrm{N}_{2} \mathrm{O}-\mathrm{N}\right.$ $\left.\mathrm{m}^{-2} \mathrm{~d}^{-1}\right)$. Rates in the other upland ecosystem types ranged from 20 to $2525 \mu \mathrm{g} \mathrm{N}{ }_{2} \mathrm{O}-\mathrm{N} \mathrm{m}^{-2} \mathrm{~d}^{-1}$ (Fig. 4). During the growing season, denitrification rates were not correlated with average daily nitrification, nor with extractable- $\mathrm{NO}_{3}^{-}$, microbial biomass $\mathrm{C}$, or microbial biomass $\mathrm{N}$ (ecosystem or site means). The relationship be-
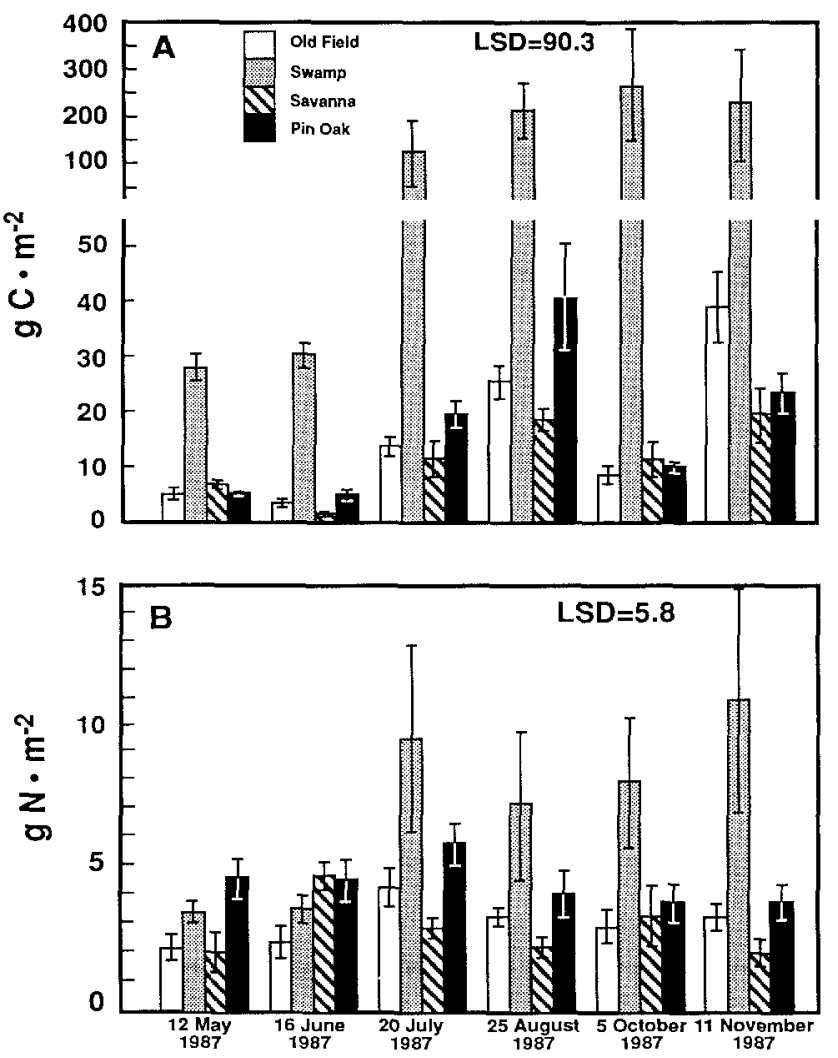

Fig. 3. Microbial $C(\mathbf{A})$ and $N(B)$ in the surface soil $(0$ to $10 \mathrm{~cm})$ of four ecosystems in east-central Minnesota. Values represent ecosystem means $(n=10)$ at five week intervals from 12 May to 11 November 1987. Standard errors are indicated

tween $\mathrm{NO}_{3}^{-}$availability and denitrification became significant when the swamp forest was eliminated from the analysis; however, even then extractable $\mathrm{NO}_{3}^{-}$and nitrification rates were poorly correlated with denitrification $\left(r^{2}=0.12\right.$ and 0.14 , respectively).

\section{Discussion}

The CCNHA is characterized by a diversity of upland and wetland ecosystems that differ in species composition, edaphic properties, and history of disturbance. Numerous studies have demonstrated the importance of these factors on $\mathrm{N}$ cycling processes and on the potential for N loss (Vitousek et al. 1982; Pastor et al. 1984; Davidson and Swank 1987). The ecosystems we studied spanned swamp forests on poorly-drained organic soils to old fields on infertile outwash sands. In addition to past agricultural activities, fire has been an important agent shaping the species composition and distribution of ecosystems (Pierce 1954; White 1983). The interaction of these factors has given rise to marked differences in $\mathrm{N}$ cycling rates within a relatively small geographic area (2300 ha). The differences among ecosystems separated by a few meters were comparable to those observed among ecosystems from diverse geographic locations.

Annual rates of net $\mathrm{N}$ mineralization in the upland pin oak ecosystem were similar to those obtained for other oak forests in the Lake States region $\left(4.9\right.$ to $8.3 \mathrm{~g} \mathrm{~N} \mathrm{~m}^{-2}$ 


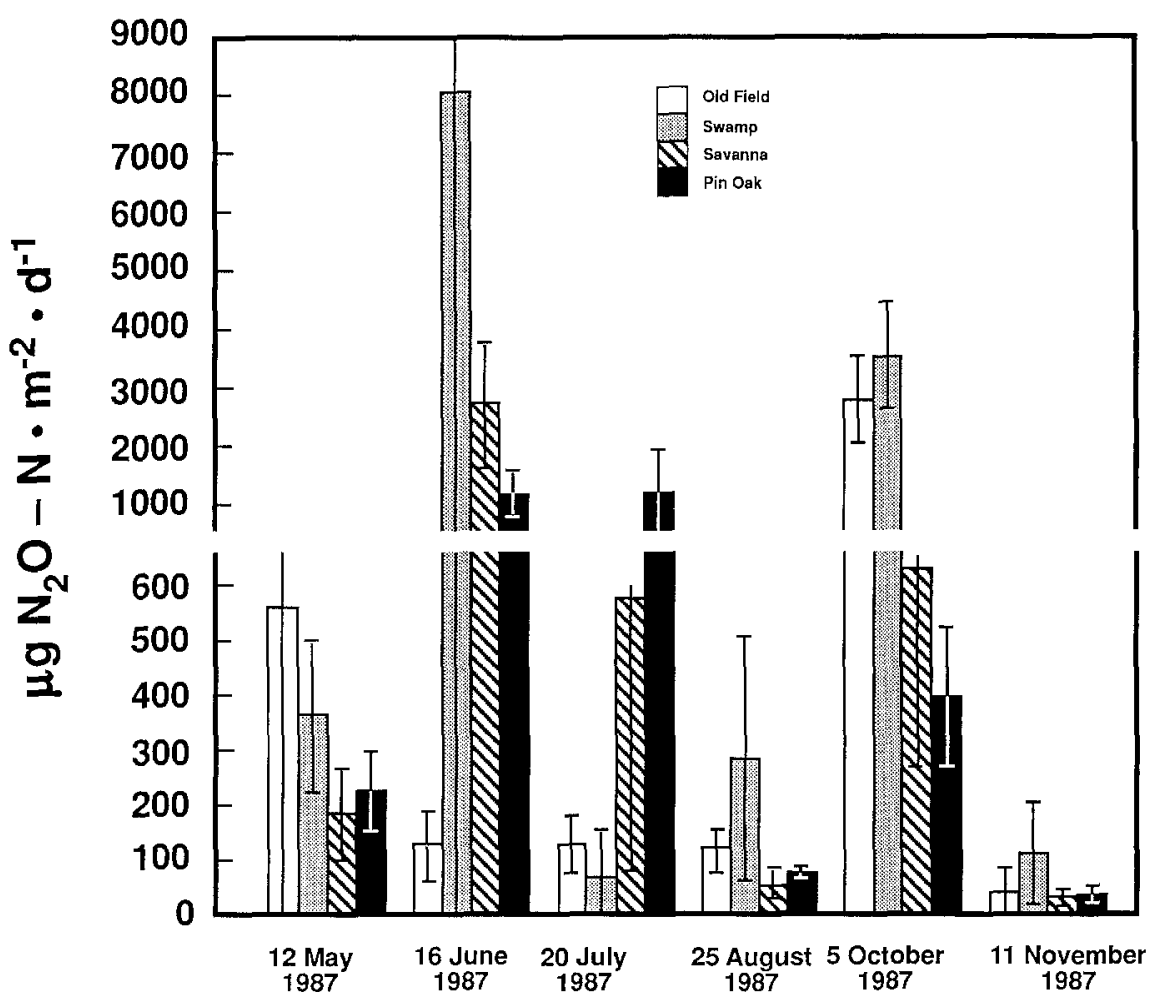

Fig. 4. Mean daily rates of denitrification $\left(\mu \mathrm{g} \mathrm{N}_{2} \mathrm{O}-\mathrm{N} \mathrm{m}^{-2} \mathrm{~d}^{-1}\right.$ ) measured in the surface soil $(0$ to $10 \mathrm{~cm})$ of upland and wetland ecosystems in east-central Minnesota $\mathrm{yr}^{-1}$, calculated from Nadelhoffer et al. 1983; Pastor et al. 1984; Zak and Pregitzer 1990; Zak et al. 1990b). However, rates within this ecosystem exhibited high spatial variation and ranged from 7.2 to $10.0 \mathrm{~g} \mathrm{~N} \mathrm{~m}^{-2} \mathrm{yr}^{-1}$ (see Table 2). Greater differences among sites have been reported in a related study ( 3.0 to $7.0 \mathrm{~g} \mathrm{~N} \mathrm{~m}^{-2} \mathrm{yr}^{-1}$ ) where annual $\mathrm{N}$ mineralization rates were well correlated to stand age and to soil organic matter content (Zak et al. 1990b). In grassland ecosystems, $\mathrm{N}$ mineralization can vary from 3.0 to $5.5 \mathrm{~g} \mathrm{~N} \mathrm{~m}^{-2} \mathrm{yr}^{-1}$ (Schimel et al. 1985; Pastor et al. 1987), and rates in the old field and savanna fell within this range. Nonetheless, mineralization still differed by a factor of two between old field sites, and by nearly as much in the savanna. Several studies have demonstrated that $\mathrm{N}$ availability is tightly coupled to soil organic matter dynamics in the CCNHA (Pastor et al. 1987; Zak et al. 1990a); mineralization rates are generally slow where disturbance has reduced soil organic matter content. This pattern was evident among the upland ecosystems, and may explain some of the variation we observed between the individual sites within them.

Because $\mathrm{N}$ mineralization is influenced by soil organic matter chemistry, the proportion of total $\mathrm{N}$ mineralized (relative $\mathrm{N}$ mineralization) can be used as an indirect index of substrate quality. During the growing season, $3 \%$ of total soil $\mathrm{N}$ was mineralized in both the old field and savanna ecosystems, suggesting that differences in $\mathrm{N}$ availability are primarily due to soil organic matter content. Relative $\mathrm{N}$ mineralization was $6 \%$ in the upland pin oak forest even though the soil C: $\mathrm{N}$ ratio (22) was comparable to those in the old field (20) and savanna (22). Pastor et al. (1987) suggested that soil organic matter quality declined during secondary succession at the
CCNHA. If the upland ecosystems represent different stages of secondary succession, then our results do not lend support for this hypothesis. The swamp forest exhibited the lowest rates of absolute and relative $\mathrm{N}$ mineralization ( $1.5 \mathrm{~g} \mathrm{~N} \mathrm{~m}^{-2} \mathrm{yr}^{-1}$ and $0.4 \%$, respectively) even though this ecosystem had the lowest $\mathrm{C}: \mathrm{N}$ ratio (14). Nitrogen availability in this ecosystem is probably more limited by seasonal inundation and anaerobic conditions than by organic matter quality.

Net nitrification, as measured by the in situ incubations, accounted for 46 to $71 \%$ of annual net mineral $\mathrm{N}$ production in the upland and wetland ecosystems. In the Lake States region, oak ecosystems occurring on coarsetextured soils typically exhibit low net nitrification rates compared to other upland forest ecosystems (Nadelhoffer et al. 1983; Pastor et al. 1984; Zak et al. 1989). Nevertheless, $71 \%$ and $58 \%$ of mineral $\mathrm{N}$ production was oxidized to $\mathrm{NO}_{3}^{-}$in the savanna and upland pin oak ecosystems, respectively. Although our results suggest that nitrification is important in the uplands, this process can be over-estimated in soil incubations where active roots and hence plant $N$ uptake have been eliminated (Zak et al. 1990c). Even if nitrification was over-estimated, the potential for $\mathrm{NO}_{3}^{-}$transport between uplands and wetlands seems minimal. Nitrate leaching generally represents less than $0.2 \%$ of annual $\mathrm{N}$ mineralization in the old field, savanna, and upland pin oak forest (Zak and Grigal, unpublished data). Moreover, the relatively low soil inorganic $\mathrm{N}$ pools, coupled with a high plant demand, further limit the possibility of $\mathrm{N}$ losses in this $\mathrm{N}$-limited landscape (Tilman 1986; 1987). More detailed studies focused on rates of $\mathrm{NO}_{3}^{-}$leaching and patterns of groundwater flow could provide further support for our conclusions. 
One could argue that rates of $\mathrm{N}$ mineralization should reach a maximum when microbial biomass is at a minimum and when gross immobilization rates are low. If this were true, then the smallest microbial $\mathrm{C}$ and $\mathrm{N}$ pools should occur during early summer when net mineralization rates were high. Our data do not lend support for this pattern, but instead suggest that a positive relationship exists between rates of net mineralization and microbial biomass. Although spatial and temporal changes in microbial biomass were not correlated to mean daily $\mathrm{N}$ mineralization rates, a significant, positive relationship exists when data are expressed as annual site means. This somewhat variable relationship suggests that $\mathrm{N}$ was mineralized in proportion to microbial biomass (on average during the growing season). Although microbial biomass $\mathrm{N}$ only explained $40 \%$ of the variation in mineralization rates, it suggests that microbial population dynamics exert some control over $\mathrm{N}$ availability.

Denitrification was an important process in the swamp forest where it consumed $14 \%$ of net nitrification (daily average from 12 May to 11 November). It accounted for much smaller proportion of net nitrification in the old field (3.9\%), savanna (4.5\%), and upland pin oak $(1.9 \%)$ ecosystems. The most rapid daily denitrification rates $\left(8040 \mu \mathrm{g} \mathrm{N} \mathrm{m}^{-2} \mathrm{~d}^{-1}\right.$ in the swamp and $2700 \mu \mathrm{g}$ $\mathrm{N} \mathrm{m}^{-2} \mathrm{~d}^{-1}$ in the savanna) extrapolate to a net loss of 0.24 and $0.08 \mathrm{~g} \mathrm{~N} \mathrm{~m}^{-2}$ month $^{-1}$ in the swamp and savanna, respectively. Nitrogen enters the CCNHA via precipitation at a rate of $0.07 \mathrm{~g} \mathrm{~N} \mathrm{~m}^{-2}$ month $^{-1}$ (or $0.9 \mathrm{~g}$ $\mathrm{N} \mathrm{m}^{-2} \mathrm{yr}^{-1}$ ); symbiotic, associative, and free-living $\mathrm{N}$ fixation are relatively unimportant inputs (McKone and Beisbor 1986; Zak and Johnson, unpublished data). In the swamp forest, $\mathrm{N}$ loss via denitrification can be 3 times greater than precipitation inputs during some portions of the year. More importantly, nitrification in the swamp forest seems to occur at rates sufficient to sustain this relatively rapid loss. Our results indirectly suggest that in situ $\mathrm{NO}_{3}^{-}$production may be sufficient to sustain denitrification in this ecosystem.

Groffman and Tiedje (1989) suggested that plant uptake was an important mechanism regulating seasonal patterns of denitrification, and similar observations have been made in other ecosystem types (Goodroad and Keeney 1984; Myrold 1988; Schmidt et al. 1988). During early spring and fall plant uptake is minimal, thus lessening competition between plants and $\mathrm{NH}_{4}^{+}$-oxidizing bacteria, and between plants and denitrifying bacteria. Greater $\mathrm{NO}_{3}^{-}$availability in the absence of plant-microbe competition, in combination with anaerobic conditions, should lead to increased rates of denitrification. Our results suggest a similar mechanism could be operating in the swamp, old field, and savanna where substantial rates of denitrification occurred during spring and fall. However, we did not observe a high degree of temporal synchrony between plant phenology and denitrification. In general, denitrification was most rapid following canopy expansion and prior to leaf fall. This was not true in the upland pin oak ecosystem where denitrification rates reached a seasonal maximum during mid-summer.

Several studies have reported significant relationships between extractable- $\mathrm{NO}_{3}^{-}$, nitrification and denitrifica- tion (Robertson and Tiedje 1984; Robertson et al. 1986, 1987). These variables were not highly correlated in this study and several factors seem to have contributed to our results. There was a considerable time lag (ca. 35 days) between high $\mathrm{NO}_{3}^{-}$availability and rapid denitrification rates during the spring and fall sampling dates. For example, nitrification rates and extractable $\mathrm{NO}_{3}^{-}$were high on 12 May, but were relatively low on 16 June when denitrification reached a seasonal peak in most ecosystems. More importantly, denitrification was consistently high in the swamp forest even though mineralization, nitrification, and extractable- $\mathrm{NO}_{3}^{-}$were relatively low compared to the upland ecosystems. The weak but significant relationship between $\mathrm{NO}_{3}^{-}$availability and denitrification when the swamp forest was eliminated from the analysis suggests that extractable- $\mathrm{NO}_{3}^{-}$and nitrification exert some control over denitrification at the spatial and temporal scale of our study.

In the subtle topography of the CCNHA, the soil water regime and soil organic matter content (as influenced by disturbance history) contribute to differences in rates of $\mathrm{N}$ cycling processes. These differences, in turn, provide feedback to influence both plant species composition and ecosystem productivity. In the poorlydrained swamp forest, denitrification was an important process even though nitrification rates on an areal basis were low compared to those measured in the upland ecosystems. Nonetheless, in situ $\mathrm{NO}_{3}^{-}$production in the swamp forest was sufficient to sustain relatively rapid denitrification rates during portions of the growing season. Nitrification and extractable- $\mathrm{NO}_{3}^{-}$seem to exert some control over denitrification in the upland ecosystems, but they only explained a small proportion of the spatial and temporal variability that we observed. Studies aimed at quantifying $\mathrm{NO}_{3}^{-}$leaching and groundwater transport, in combination with our results, could provide a more complete understanding of the link between $\mathrm{N}$ availability and loss among these ecosystems.

Acknowledgements. This research was supported by an NSF grant (BSR 881184) for Long-Term Ecological Research at the Cedar Creek Natural History Area, and by project 25-054 of the University of Minnesota Agricultural Experiment Station. Published as article 19110 in the Scientific Journal Series of the Minnesota Agricultural Experiment Station. We thank Barb Delaney, Karen Updegraff, and Sandy Brovold for their assistance in field and laboratory. Our $\mathrm{N}_{2} \mathrm{O}$ analysis was conducted in the laboratory of Bill Caskey, USDA-ARS, Morris, MN; we are grateful for his assistance. Bob McKane provided useful comments during this project, and we gratefully acknowledge Bill Holmes and Diana Randlett for their valuable contributions to all aspects of data analysis. We thank Neil MacDonald, Bill Holmes, Amy Merrill, and two anonymous reviewers for useful comments on a earlier draft of this manuscript.

\section{References}

Burke IC (1989) Control of nitrogen mineralization in a sagebrush steppe landscape. Ecology 70:1115-1126

Davidson EA, Swank WT (1987) Factors limiting denitrification in soils from mature and disturbed southeastern hardwood forests. Forest Science 33:135-144 
Engler RM, Patrick WH (1974) Nitrate removal from floodwater overlying flooded soils and sediments. J Environ Qual $3: 409-413$

Goodroad LL, Keeney DR (1984) Nitrous oxide emission from forest, marsh, and prairie ecosystems. J Environ Qual $13: 448-452$

Groffman PM, Tiedje JM (1989) Denitrification in north temperate forest soils: spatial and temporal patterns at the landscape and seasonal scales. Soil Biol Biochem 21:613-620

Grigal DF, Chamberlain LM, Finney HR, Wroblewski DV, Gross ER (1974) Soils of the Cedar Creek Natural History Area. Miscellaneous Report 123, University of Minnesota Agricultural Experiment Station, St. Paul, MN, USA

Jackson WA, Asmussen LE, Hauser EW, White AW (1973) Nitrate in surface and subsurface flow from a small agricultural watershed. J Environ Qual 2:480-482

Jenkinson DS, Powlson DS (1976) The effects of biocidal treatments on metabolism in soil V. A method for measuring soil biomass. Soil Biol Biochem 8:208-213

Kitchens WM, Dean JM, Stevenson LM, Cooper JH (1975) The Santee Swamp as a nutrient sink. p. 349-366. In: Howell (ed) Mineral cycling in southeastern ecosystems ERDA Symp. Series (CONF-740513) US Government Printing Office, Washington DC

Lowrance R, Todd R, Fail J, Hendrickson Jr. O, Leonard R, Asmussen L (1984a) Riparian forests as nutrient filters in agricultural watersheds. Bioscience 34:374-377

Lowrance RR, Todd RL, Asmussen LE (1984b) Nutrient cycling in an agricultural watershed: II. stream and artificial drainage. Journal of Environmental Quality 13:27-32

McKone MJ, Biesboer DD (1986) Nitrogen fixation in association with the root systems of goldenrods (Solidago L.). Soil Biol Biochem 18:543-545

Matson PA, Vitousek PM (1987) Cross-system comparisons of soil nitrogen transformations and nitrous oxide flux in tropical forest ecosystems. Global Biogeoch Cycl 1:163-170

Myrold DD (1988) Denitrification in ryegrass and winter wheat cropping systems of western Oregon. Soil Science Soc Am J $52: 412-416$

Nadelhoffer NJ, Aber JD, Melillo JM (1983) Leaf-litter production and soil organic matter dynamics along a nitrogen-availability gradient in southern Wisconsin. Can J Forest Res 13:12-21

Parkin TB, Kaspar HF, Sexstone AJ, Tiedje JM (1984) A gas-flow soil core method to measure field denitrification rates. Soil Biol Biochem 16:323-330

Pastor J, Aber JD, McClaugherty CA, Melillo JM (1984) Aboveground production and $\mathrm{N}$ and $\mathrm{P}$ cycling along a nitrogen mineralization gradient on Blackhawk Island, Wisconsin. Ecology $65: 256-268$

Pastor J, Stillwell MA, Tilman D (1987) Nitrogen mineralization and nitrification in four Minnesota old fields. Oecologia $71: 481-485$

Peterjohn WT, Correll DL (1984) Nutrient dynamics in an agricultural watershed: observations on the role of a riparian forest. Ecology $65: 1466-1475$

Pierce RL (1954) Vegetation cover types and land use history of the Cedar Creek Natural History Reservation, Anoka and Isanti Counties, Minnesota. Thesis, University of Minnesota, Minneapolis, Minnesota, USA

Rapp M, LeClerc MC, Loissant P (1979) The nitrogen economy in a Pinus pinea stand. Forest Ecol Manag 2:221-231
Robertson GP (1986) Nitrogen: regional contributions to the global cycle. Environment 28:16-21

Robertson GP, Tiedje JM (1984) Denitrification and nitrous oxide production in successional and old-growth Michigan forests. Soil Science Soc Am J 48:383-389

Robertson GP, Vitousek PM, Matson PA, Tiedje JM (1987) Denitrification in a clearcut loblolly pine (Pinus taeda L.) plantation in the southeastern U.S. Plant \& Soil 97:119-129

SAS Institute (1987) SAS/STAT Guide for Personal Computers, Version 6 Edition, SAS Institute, Cary NC, $1028 \mathrm{pp}$

Schimel D, Stillwell MA, Woodmansee RG (1985) Biogeochemistry of $\mathrm{C}, \mathrm{N}$, and $\mathrm{P}$ in a soil catena of the shortgrass steppe. Ecology $66: 276-282$

Schmidt J, Seiler W, Conrad R (1988) Emission of nitrous oxide from temperate forest soils into the atmosphere. J Atmosph Chem 6:95-115

Technicon Instruments (1977) Nitrate and nitrite in water and seawater. Technicon Industrial Systems, Terrytown, NY. Industrial Method Number 158-71W

Technicon Instruments (1978) Ammonia in water and seawater. Technicon Industrial Systems, Terrytown, NY. Industr Meth Number $154-78 \mathrm{~W} / \mathrm{B}$

Tiedje JM (1982) Denitrification. pp. 1011-1026. In: Page AL, Miller RH, and Keeney DS (eds.) Methods of soil analysis. Part 2. Chemical and microbiological properties. $2^{\text {nd }} \mathrm{Ed}$. Agronomy No. 9. ASA, Madison, Wisconsin

Tiedje JM, Simkins S, Groffman PM (1989) Perspectives on measurement of denitrification in the field including recommended protocols for acetylene based methods. Plant Soil 115:261-284

Tilman D (1986) Nitrogen-limited growth in plants from different successional stages. Ecology 67:555-563

Tilman D (1987) Secondary successional and the pattern of plant dominance along experimental nitrogen gradients. Ecol Monogr 57: $189-214$

Verry ES, Timmons DR (1982) Waterborne nutrient flow through an upland-peatland watershed in Minnesota. Ecology 63:1456-1467

Vitousek PM, Gosz JR, Greir CC, Melillo JM, Reiners WA (1982) A comparative analysis of potential nitrification and nitrate mobility in forest ecosystems. Ecol Monogr 52:155-177

Voroney RP, Paul EA (1984) Determination of $k_{c}$ and $k_{n}$ in situ for calibration for the chloroform fumigation-incubation method. Soil Biol Biochem 16:9-14

White AS (1983) The effects of thirteen years of annual prescribed burning on a Quercus ellipsoidalis community in Minnesota. Ecology 64: 1081-1085

Zak DR, Pregitzer KS (1990) Spatial and temporal variability of nitrogen cycling in northern Lower Michigan. Forest Science $36: 367-380$

Zak DR, Host GE, Pregitzer KS (1989) Regional variability in nitrogen mineralization, nitrification and overstory biomass in northern Lower Michigan. Can J For Res 19:1521-1526

Zak DR, Grigal DF, Gleeson S, Tilman D (1990a) Carbon and nitrogen cycling during secondary succession: constraints on plant and microbial biomass. Biogeochemistry 11:111-129

Zak DR, Hairston AB, Grigal DF (1990b) Topographic influences on nitrogen cycling within an upland pin oak ecosystem. Forest Science 37:45-53

Zak DR, Groffman PM, Pregitzer KS, Christensen C, Tiedje JM (1990c) The vernal dam: plant-microbe competition for nitrogen in northern hardwood forests. Ecology 71:651-656 